\title{
CORRECTION
}

\section{Correction to: Origins, admixture and founder lineages in European Roma}

Begoña Martínez-Cruz, Isabel Mendizabal, Christine Harmant, Rosario de Pablo, Mihai loana, Dora Angelicheva, Anastasia Kouvatsi, Halyna Makukh, Mihai G. Netea, Horolma Pamjav, Andrea Zalán, Ivailo Tournev, Elena Marushiakova, Vesselin Popov, Jaume Bertranpetit, Luba Kalaydjieva, Lluis Quintana-Murci, David Comas and the Genographic Consortium*

(c) The Author(s), under exclusive licence to European Society of Human Genetics 2021

European Journal of Human Genetics (2022) 30:490; https://doi.org/10.1038/s41431-021-01020-7

Correction to: European Journal of Human Genetics https://www. nature.com/articles/ejhg2015201, published online 16 September 2015
Access to the supplementary Tables in this article has been removed because of concerns that the data presented could be potentially identifiable. 